\title{
PENGARUH MODEL PEMBELAJARAN \\ KOOPERATIF TIPE STUDENT TEAMS ACHIEVEMENT DIVISION (STAD) TERHADAP KEMAMPUAN PEMAHAMAN KONSEP MATEMATIS SISWA KELAS VIII SMP
}

\author{
Four Marito Marbun \\ Universitas Katolik Santo Thomas, Medan; \\ fourmaritomarbun@gmail.com
}

\begin{abstract}
Abstrak. Tujuan penelitian ini adalah untuk mengetahui pengaruh model pembelajaran cooperative Student Teams Achievement Devision (STAD) terhadap kemampuan pemahaman konsep matematis siswa dan respon siswa terhadap model pembelajaran koperatif tipe STAD. Metode penelitian ini adalah metode eksperimen kuasi. Penelitian ini dilaksanakan di SMP Negeri 2 Sorkam pada semester genap tahun Ajaran 2016/2017. Sampel penelitian ini adalah kelas VIIIA sebagai kelas eksperiman dan VIIIB sebagai kelas kontrol. Dari data penelitian diperoleh persamaan regresi $\mathrm{Y}=74,857+8,857 \mathrm{X}$ (ada pengaruh positif). Nilai rata-rata kemampuan pemahaman konsep matematis siswa yang dibelajarkan dengan model pembelajaran kooperatif tipe STAD sebesar 83,714, sementara dengan model pembelajaran konvesional sebesar 74,857. Koefisien determinasi sebesar $21,6 \%$, artinya $21,6 \%$ pengaruh model pembelajaran koperatif tipe STAD terhadap kemampuan pemahaman konsep matematis siswa. Hasil analisis respon siswa diperoleh (1) sebesar 98,2\% menyatakan tertarik dan sisanya tidak; (2) sebesar 95,05\% menyatakan ada manfaat yang didapatkan dan sisanya tidak; (3) sebesar 86,78\% menyatakan tidak ada kendala yang dialami selama proses pembelajaran dan sisanya menyatakan ada; (4) sebesar $94,04 \%$ berharap model pembelajaran koperatif tipe STAD digunakan dalam proses pembelajaran dan sisanya tidak berharap. Jadi, dapat disimpulkan respon siswa sangat positif karena rata-rata persentase respon persetujuan siswa terhadap model pembelajaran koperatif tipe STAD $\geq 85 \%$.
\end{abstract}

Kata Kunci. Pembelajaran koperatif STAD, pemahaman konsep matematis

Cartesius: Jurnal Pendidikan Matematika Vol. 2, No. 1

CProdi Pendidikan Matematika Universitas Katolik Santo Thomas 


\begin{abstract}
The purpose of this study was to determine the effect of the cooperative Student Teams Achievement Devision (STAD) learning model on the ability to understand students 'mathematical concepts and students' responses to the STAD cooperative learning model type. This research method is a quasi experimental method. This research was conducted in State 2 Junior High School of Sorkam at the even semester of the 2016/2017 Academic Year. The sample of this study was class VIIIA as the experimental class and VIIIB as the control class. From the research data obtained a regression equation $Y=$ $74,857+8.857 X$ (there is a positive effect). The average value of students' understanding of mathematical concepts learned by the STAD cooperative learning model is 83,714 , while the conventional learning model is 74,857 . The coefficient of determination is $21.6 \%$, meaning that $21.6 \%$ of the influence of the STAD type cooperative learning model on the ability to understand students' mathematical concepts. The results of the analysis of student responses were obtained (1) by $98.2 \%$ stating they were interested and the rest not; (2) amounting to $95.05 \%$ stating that there are benefits obtained and the rest not; (3) amounting to $86.78 \%$ stated that there were no obstacles experienced during the learning process and the rest stated there were; (4) 94.04\% hoped the STAD type cooperative learning model was used in the learning process and the rest did not expect. So, it can be concluded that the student response is very positive because the average percentage of student approval responses to the STAD type cooperative learning model is $\geq 85 \%$.
\end{abstract}

Keywords. Cooperative learning, STAD, understanding mathematical concepts

\title{
PENDAHULUAN
}

Pendidikan merupakan hal yang penting bagi setiap manusia, karena dengan pendidikan manusia dapat mengembangkan potensi dirinya untuk mencapai kesejahteraan hidup. Pendidikan dapat mewujudkan sumber daya manusia yang berkualitas terutama mempersiapkan peserta didik sebagai generasi penerus bangsa yang kompeten, mandiri, kritis, kreatif serta sanggup menyelesaikan permasalahan yang akan dihadapi.

Pendidikan merupakan sebuah sistem yang terbangun dalam beberapa komponen, yaitu pendidik, peserta didik, tujuan pendidikan, alat pendidikan, dan lingkungan pendidikan dimana ada aktivitas yang dilakukan [1]. Selain itu pendidikan merupakan suatu proses transfer ilmu,

Cartesius: Jurnal Pendidikan Matematika Vol. 2, No. 1

CProdi Pendidikan Matematika Universitas Katolik Santo Thomas 
nilai, dan pembentukan kepribadian dalam segala cakupan aspek, yang lebih dari sekedar pengajaran [2].

Pendidikan sangat dipengaruhi oleh perkembangan ilmu pengetahuan dan teknologi dan tidak terlepas dari perkembangan ilmu-ilmu yang mendasarinya. Salah satu ilmu yang mendasarinya adalah matematika. Matematika merupakan bidang studi yang dipelajari oleh semua orang sejak usia dini. Ada banyak alasan tentang perlunya siswa belajar matematika. Seperti yang dikemukakan oleh Cockroft bahwa matematika perlu diajarkan kepada siswa karena (1) selalu digunakan dalam segala segi kehidupan; (2) semua bidang studi memerlukan keterampilan matematika yang sesuai; (3) merupakan sarana komunikasi yang kuat, singkat, dan jelas; (4) dapat digunakan untuk menyajikan informasi dalam berbagai cara; (5) meningkatkan kemampuan berpikir logis, ketelitian, dan kesadaran keruangan; dan (6) memberikan kepuasan terhadap usaha memecahkan masalah yang menantang [3].

Matematika adalah pelajaran yang diajarkan mulai dari tingkat TK, SD, SMP, SMA bahkan perguruan tinggi. Dengan belajar matematika maka siswa dapat memahami konsep, bernalar, memecahkan masalah, serta memiliki sikap menghargai matematika dan memiliki kemampuan komunikasi. Salah satu tujuan dari pembelajaran matematika adalah meningkatkan kemampuan pemahaman konsep matematika. Oleh karena itu perlu ditanamkan kepada peserta didik sejak dini. Tanpa disadari sebenarnya matematika merupakan bagian dalam kehidupan dan yang dibutuhkan kapan dan dimana saja sehingga matematika menjadi hal yang penting [4]. Namun dalam pembelajaran matematika masih terdapat siswa-siswa mengalami kendala-kendala dalam pembelajaran matematika yang menyebabkan siswa gagal dalam pelajaran ini. Jika dilihat dari keadaan di lapangan masih belum sesuai dengan yang diharapkan, kemampuan memahami konsep matematika belum optimal, salah satunya terlihat dalam memahami materi sistem persamaan linear dua variabel (SPLDV). Hal tersebut didukung berdasarkan minitest yang dilakukan terhadap siswa SMPN 2 Sorkam yaitu pada kelas VIII B pada tanggal 26 April 2017 yang

Cartesius: Jurnal Pendidikan Matematika Vol. 2, No. 1

CProdi Pendidikan Matematika Universitas Katolik Santo Thomas 
menyimpulkan bahwa, dari 30 siswa, 12 orang (40\%) yang mampu memahami soal, melaksanakan proses yang benar dan mendapat solusi atau hasil yang benar. Sedangkan jawaban siswa yang memahami soal dan menggunakan strategi yang benar, tetapi ada sedikit salah dalam perhitungan sebanyak 3 orang (10\%). Dan memahami soal, melaksanakan prosedur yang benar, memberikan jawaban yang benar tetapi salah dalam struktur atau perhitungan sebanyak 6 orang (20\%). Selebihnya siswa kesulitan dalam membuat model matematika serta menyelesaikan model matematikanya.

Berikut merupakan contoh penyelesaian siswa dalam menjawab soal cerita Sistem Persamaan Linear Dua Variabel (SPLDV): “Anas membeli 5 kg gula dan 2 liter minyak goreng di toko "SERBA MURAH" seharga Rp. 72.000,sedangkan Anis membeli 2 kg gula dan 6 liter minyak goreng yang sama dan sejenis seharga Rp. 73.000,-. Tentukan harga masing-masing $1 \mathrm{~kg}$ gula dan 1 liter minyak goreng jenis tersebut!"

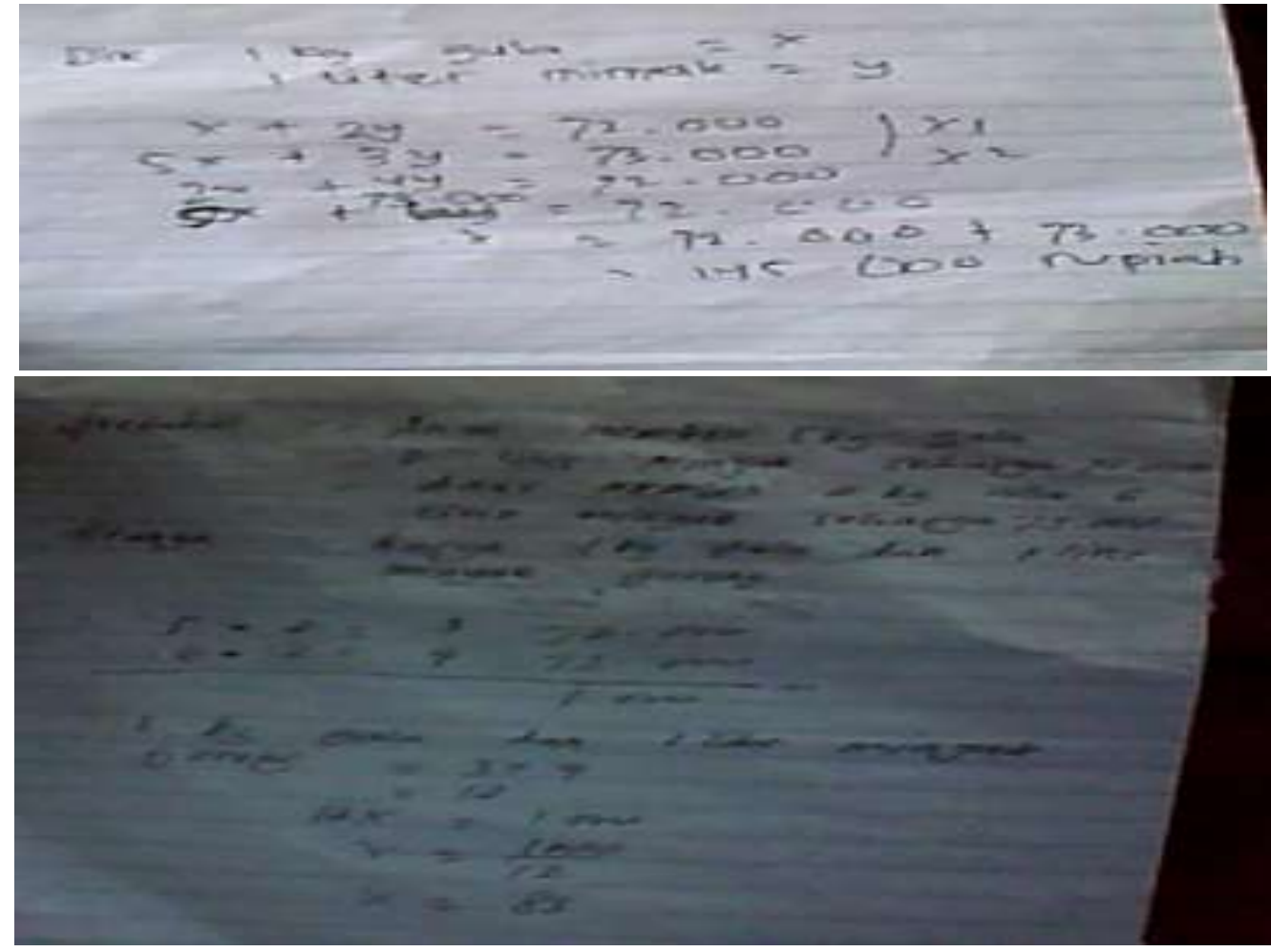

Gambar 1. Hasil Penyelesaian Uji Tes Pemahaman Konsep Matematis Siswa Sebelum Pra Penelitian

Cartesius: Jurnal Pendidikan Matematika Vol. 2, No. 1

CProdi Pendidikan Matematika Universitas Katolik Santo Thomas 
Berdasarkan gambar di atas menunjukkan bahwa hasil pekerjaan siswa dalam menyelesaikan soal cerita tidak sesuai dengan jawaban yang benar. Hal ini disebabkan karena siswa masih kesulitan dalam membuat model matematika, masih kesulitan dalam memisalkan variabel yang digunakan untuk membuat model matematika dan kebingungan dalam memahami soal sehingga salah dalam pemisalan bentuk aljabar. Kondisi ini jelas menggambarkan bahwa pemahaman konsep siswa dalam pembelajaran matematika harus terus diperbaiki/ditingkatkan.

Berdasarkan dari hasil wawancara dengan Bapak Edison Lumban Gaol selaku guru matematika di SMPN 2 Sorkam, diperoleh informasi bahwa proses pembelajaran matematika yang dilakukan kurang maksimal, hal tersebut dilihat dari: (1) nilai Kriteria Ketuntasan Minimal (KKM) masih rendah yaitu 66; (2) pembelajaran yang dilakukan masih terpusat pada guru; (3) Saat diberikan latihan, guru hanya terfokus pada siswa yang mampu menyelesaikan soal sehingga guru berasumsi bahwa siswa yang lain sudah memahami materi yang dijelaskan. Kegiatan ini cenderung membuat siswa hanya meniru dan menghafal apa yang disampaikan guru tanpa adanya pemahaman. Hal ini menandakan bahwa kemampuan pemahaman konsep matematis siswa masih rendah. Guru matematika di sekolah SMP Negeri 2 Sorkam, telah berupaya meningkatkan kemampuan pemahaman konsep matematis siswa dengan menerapkan metode diskusi, tanya-jawab, dan pemberian tugas dalam pembelajaran. Namun, upaya tersebut belum cukup untuk meningkatkan kemampuan pemahaman konsep matematis siswa.

Kendala dalam dunia pendidikan seringkali terjadi yang berhubungan dengan model pembelajaran, pendekatan, media pembelajaran dan penilaian pada siswa [5]. Oleh karena itu diharapkan guru mampu mengupayakan supaya kendala itu bisa diatasi. Slameto menyatakan bahwa dalam proses dan kegiatan belajar-mengajar, peran guru sangatlah penting, karena tugas guru adalah mendorong, membimbing, dan memfasilitasi siswa belajar untuk mencapai tujuan [6]. Oleh karena itu guru hendaknya mampu melakukan inovasi pembelajaran sehingga menjadi menarik, serta memilih dan menerapkan model pembelajaran yang tepat dan sesuai dengan

Cartesius: Jurnal Pendidikan Matematika Vol. 2, No. 1

CProdi Pendidikan Matematika Universitas Katolik Santo Thomas 
kurikulum yang berlaku. Selain itu, siswa juga dapat berbagi dan bertukar informasi dengan siswa lain. Salah satu cara untuk melibatkan siswa secara aktif adalah menerapkan model pembelajaran kooperatif tipe Student Teams Achievement Division (STAD). Pembelajaran kooperatif tipe Student Teams Achievement Division (STAD) yaitu suatu sistem pembelajaran yang memberikan kesempatan kepada siswa untuk belajar satu sama lain untuk memastikan bahwa tiap anggota dalam kelompok telah menguasai konsepkosep yang telah dibahas.

Model pembelajaran koperatif tipe STAD dapat berpengaruh terhadap kemampuan pemahaman konsep matematis siswa. Hal tersebut didukung oleh hasil penelitian Nicke Yulanda (2014) bahwa terdapat pengaruh model pembelajaran koperatif tipe STAD terhadap hasil belajar matematika siswa dengan analisis data menggunakan $t$ dengan 0,05 menunjukkan thituung $=2,371$ $>t_{\text {tabel }}=1,669$ maka Ho ditolak dan Ha diterima yang berarti bahwa pemahaman konsep matematika siswa dengan menggunakan model pembelajaran koperatif tipe STAD lebih baik daripada pemahaman konsep matematikas siswa dengan menggunakan pendekatan konvesional.

Dengan demikian berdasarkan latar belakang yang telah dipaparkan, maka perlu diadakan penelitian tentang Pengaruh Model Pembelajaran Kooperatif Tipe Student Teams Achievement Division (STAD) Terhadap Kemampuan Pemahaman Konsep Matematis Siswa Kelas VIII SMP Negeri 2 Sorkam Tahun Ajaran 2017/2018.

\section{METODE}

Penelitian ini merupakan penelitian eksperimen semu (quasi eksperiment) yang membandingkan dua model pembelajaran yaitu model pembelajaran kooperatif tipe STAD dan model pembelajaran konvesional. Pendekatan yang digunakan dalam penelitian ini adalah pendekatan kuantitatif dan kualitatif. Desain penelitian ini menggunakan pretest-posttest control group design yang ditunjukkan pada tabel berikut:

Cartesius: Jurnal Pendidikan Matematika Vol. 2, No. 1

CProdi Pendidikan Matematika Universitas Katolik Santo Thomas 
Tabel 1. Pretest-Posttest Control Group Design

\begin{tabular}{cccc}
\hline $\mathrm{R}$ & $\mathrm{O}_{1}$ & $\mathrm{X}$ & $\mathrm{O}_{2}$ \\
\hline $\mathrm{R}$ & $\mathrm{O}_{3}$ & - & $\mathrm{O}_{4}$ \\
\hline
\end{tabular}

Keterangan :

$\mathrm{R} \quad$ : Random pretest, posttest

$\mathrm{X} \quad$ : perlakuan terhadap kelompok eksperimen menggunakan model pembelajaran kooperatif tipe STAD

$\mathrm{O}_{1} \quad$ : pretest kelas eksperimen

$\mathrm{O}_{2} \quad$ : posttest kelas eksperimen

$\mathrm{O}_{3} \quad$ : pretest kelas kontrol

$\mathrm{O}_{4} \quad$ : posttest kelas kontrol

Tempat penelitian dilakukan di SMP Negeri 2 Sorkam yang berlokasi di Jl. Sibolga-Barus Naipospos Barat Kec. Sorkam, kota Sibolga. Waktu pelaksanaan penelitian dilaksanakan pada semester genap tahun Ajaran 2016/2017. Populasi dalam penelitian ini adalah semua siswa kelas VIII SMPN 2 Sorkam, yang terdiri dari 3 kelas dengan jumlah siswa sebanyak 84 orang, seperti terlihat pada tabel dibawah ini:

Tabel 2. Populasi Kelas VIII SMP Negeri 2 Sorkam

\begin{tabular}{ccc} 
& \multicolumn{2}{c}{ Tahun Ajaran $2017 / 2018$} \\
\hline No. & Kelas & Jumlah Siswa \\
\hline 1 & Kelas VIII-A & 28 orang \\
2 & Kelas VIII-B & 28 orang \\
3 & Kelas VIII-C & 28 orang \\
\hline & Jumlah & 84 orang \\
\hline
\end{tabular}

Untuk teknik pengambilan sampel yang digunakan dalam penelitian ini yaitu teknik random sampling (secara acak). Terpilih dua kelas VIIIA dan VIIIB dengan jumlah siswa masing-masing untuk kelas adalah sebanyak 28 siswa. Selanjutnya dari dua kelas yang terpilih secara acak, dilakukan pemilihan kembali secara acak sehingga diperoleh kelas VIIIA dengan pembelajaran kooperatif tipe STAD dan kelas VIIIB dengan pembelajaran konvesional.

Cartesius: Jurnal Pendidikan Matematika Vol. 2, No. 1

CProdi Pendidikan Matematika Universitas Katolik Santo Thomas 
Adapun rancangan penelitian yang akan dilaksanakan dapat dilihat pada bagan berikut ini:

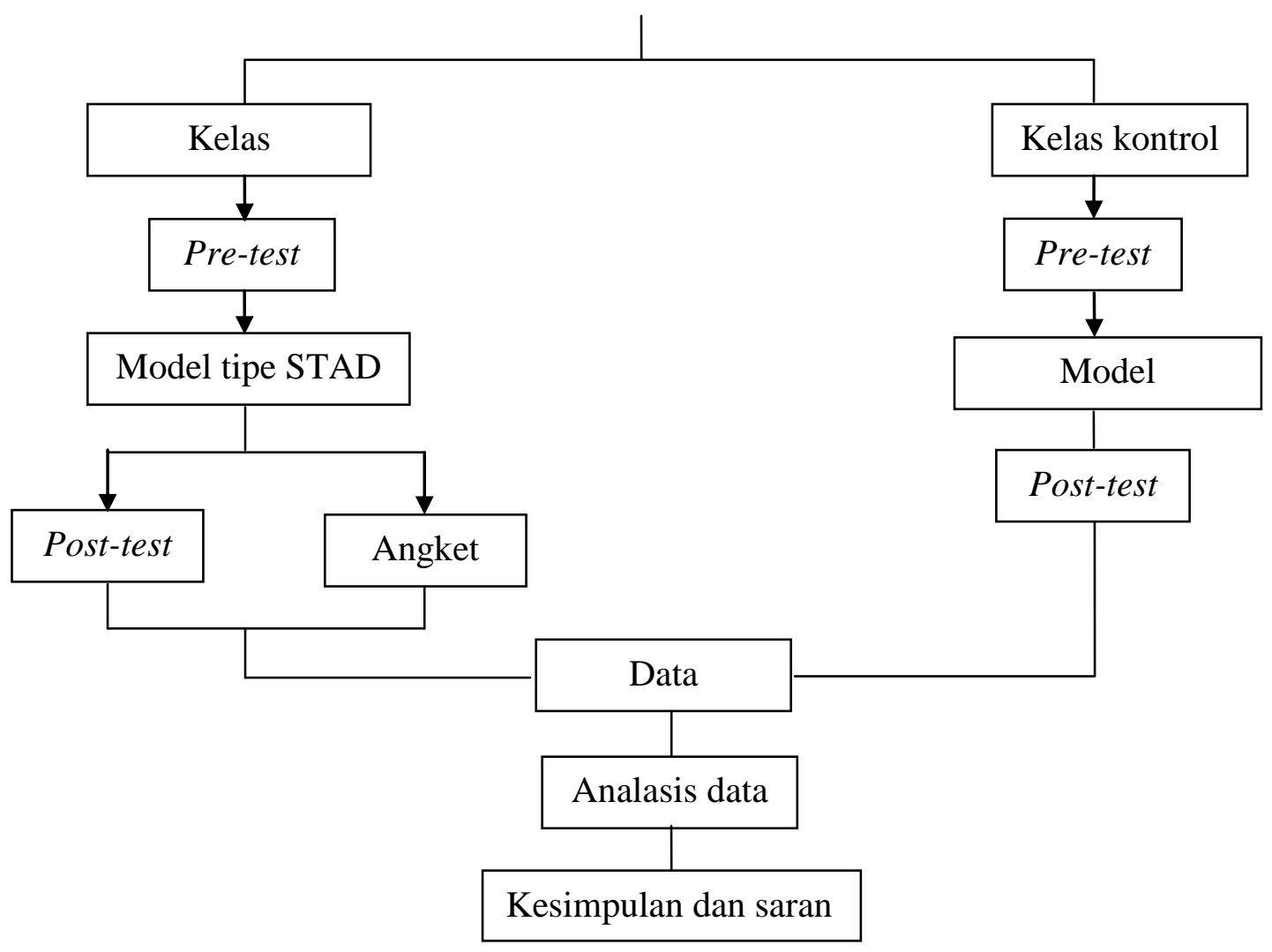

Gambar 2. Rancangan Penelitian

Jenis data yang digunakan adalah data kuantitatif dan data kualitatif. Dalam penelitian ini alat pengumpulan data yang digunakan peneliti adalah tes dan angket (kuesioner). Dalam ujicoba instrumen tes kemampuan pemahaman konsep matematis siswa perlu dilakukan uji instrumen yaitu uji validitas, reliabilitas, daya pembeda, dan uji tingkat kesukaran instrumen penelitian. Ujicoba tes dilaksanakan di SMP Swasta Dharma Bakti Medan pada siswa kelas IX dengan jumlah siswa 20 orang. Sedangkan validasi perangkat pembelajaran dilakukan oleh ahli yaitu dosen. Berikut ini merupakan hasil rekapitulasi analisis ujicoba instrumen tes.

Cartesius: Jurnal Pendidikan Matematika Vol. 2, No. 1

CProdi Pendidikan Matematika Universitas Katolik Santo Thomas 
Tabel 3. Rekapitulasi Analisis Ujicoba Tes Kemampuan Pemahaman Konsep Matematis Siswa

\begin{tabular}{|c|c|c|c|c|c|c|c|c|c|c|}
\hline \multirow{2}{*}{\multicolumn{2}{|c|}{ Jenis data }} & \multirow{2}{*}{$\begin{array}{l}\text { No } \\
\text { soal }\end{array}$} & \multicolumn{2}{|c|}{ Validasi } & \multicolumn{2}{|c|}{ Reliabilitas } & \multicolumn{2}{|c|}{$\begin{array}{c}\text { Daya } \\
\text { Pembeda }\end{array}$} & \multicolumn{2}{|c|}{$\begin{array}{c}\text { Tingkat } \\
\text { Kesukaran }\end{array}$} \\
\hline & & & $\begin{array}{c}\begin{array}{c}\text { Koef. } \\
\text { kor }\end{array}\end{array}$ & $\begin{array}{c}\text { Inter } \\
\text { prestasi }\end{array}$ & $\begin{array}{c}\begin{array}{c}\text { Koef. } \\
\text { kor }\end{array}\end{array}$ & $\begin{array}{c}\text { Inter } \\
\text { pretasi }\end{array}$ & $\begin{array}{l}\text { Koef. } \\
\text { Kor }\end{array}$ & $\begin{array}{c}\text { Inter } \\
\text { pretasi }\end{array}$ & $\begin{array}{c}\text { Koef. } \\
\text { kor }\end{array}$ & $\begin{array}{c}\text { Inter } \\
\text { Pretasi }\end{array}$ \\
\hline $\mathrm{P}$ & $p$ & 1 & 0,788 & Valid & \multirow{7}{*}{0,784} & \multirow{7}{*}{$\begin{array}{l}\text { Ting } \\
\text { gi }\end{array}$} & 0,58 & Baik & 0,63 & Sedang \\
\hline e & $r$ & 2 & 0,573 & Valid & & & 0,28 & Cukup & 0,56 & Sedang \\
\hline $\mathrm{m}$ & $e$ & 3 & 0,83 & Valid & & & 0,3 & Cukup & 0,64 & Sedang \\
\hline $\mathrm{a}$ & $t$ & 4 & 0,813 & Valid & & & 0,36 & Cukup & 0,36 & Sedang \\
\hline $\mathrm{h}$ & $e$ & & & & & & & & & \\
\hline a & s & 5 & 0,734 & Valid & & & 0,22 & Cukup & 0,50 & Sedang \\
\hline $\mathrm{m}$ & $t$ & & & & & & & & & \\
\hline \multirow{3}{*}{$\begin{array}{l}\mathrm{a} \\
\mathrm{n}\end{array}$} & & 1 & 0,748 & Valid & \multirow{9}{*}{0,637} & \multirow{9}{*}{$\begin{array}{l}\text { Ting } \\
\text { gi }\end{array}$} & 0,58 & Baik & 0,52 & Sedang \\
\hline & $P$ & 2 & 0,573 & Valid & & & 0,28 & Cukup & 0,5 & Sedang \\
\hline & $o$ & 3 & 0,583 & Valid & & & 0,3 & Cukup & 0,43 & Sedang \\
\hline $\mathrm{k}$ & s & 4 & 0,805 & Valid & & & 0,36 & Cukup & 0,4 & Sedang \\
\hline $\mathrm{o}$ & $t$ & \multirow{5}{*}{5} & \multirow{5}{*}{0,543} & \multirow{5}{*}{ Valid } & & & \multirow{5}{*}{0,22} & \multirow{5}{*}{ Cukup } & 0,49 & \multirow{5}{*}{ Sedang } \\
\hline $\mathrm{n}$ & $e$ & & & & & & & & & \\
\hline $\mathrm{s}$ & S & & & & & & & & & \\
\hline e & $t$ & & & & & & & & & \\
\hline$p$ & & & & & & & & & & \\
\hline
\end{tabular}

Berdasarkan tabel 3 di atas dapat disimpulkan bahwa soal pretest dan posttest kemampuan pemahaman konsep matematis siswa dapat dipergunakan sebagai alat ukur untuk mengetahui kemampuan pemahaman konsep matematis siswa. Karena ujicoba yang telah dilakukan berhasil memenuhi syarat yang telah ditentukan.

Sebelum dilakukan uji hipotesis penelitian, terlebih dahulu harus dilakukan uji prasyarat analisis yaitu uji normalitas dan homogenitas. Dalam pengujian hipotesis penelitian ini akan diuji dengan menggunakan analisis regresi linear sederhana dan korelasi. 


\section{HASIL DAN PEMBAHASAN}

\section{HASIL}

Secara umum dideskripsikan kedua kelompok data pretest dan post test kemampuan pemahaman konsep matematis siswa untuk kelas eksperimen dan kelas control pada table 4 berikut:

Tabel 4. Data Pretest, Posttest, Kemampuan Pemahaman

\begin{tabular}{ccccc} 
& \multicolumn{3}{c}{ Konsep Matematis Siswa } \\
\hline \multirow{2}{*}{ Statistik } & \multicolumn{2}{c}{ Pretest } & \multicolumn{2}{c}{ Posttest } \\
\cline { 2 - 5 } & Tipe STAD & Konvesional & Tipe & Konvesional \\
& & & STAD & \\
\hline N & 28 & 28 & 28 & 28 \\
Rata-rata & 64,14 & 60 & 83,71 & 74,86 \\
Std.dev & 8,11 & 10,15 & 8,14 & 9,03 \\
\hline
\end{tabular}

Secara deskriptif ada beberapa kesimpulan yang berkenaan dengan kemampuan pemahaman konsep matematis siswa yang dapat dilihat pada tabel di atas yaitu:

a. Rata-rata pretest kemampuan pemahaman konsep matematis siswa yang pembelajarannya menerapkan model pembelajaran koperatif tipe STAD yaitu 64,14 lebih tinggi dibandingkan dengan rata-rata pretest yang pembelajarannya menerapkan model pembelajaran konvesional yaitu 60 .

b. Rata-rata posttest kemampuan pemahaman konsep matematis siswa yang pembelajarannya menerapkan model pembelajaran koperatif tipe STAD yaitu 83,71 lebih tinggi dibandingkan dengan rata-rata posttest yang pembelajarannya menerapkan model pembelajaran konvesional yaitu 74,36 .

c. Standart deviasi pretest dan posttest kemampuan pemahaman konsep matematis siswa yang pembelajarannya menerapkan model pembelajaran koperatif tipe STAD yaitu 8,11 dan 8,14 terlihat lebih rendah dibandingkan dengan standart deviasi pretest dan posttest yang pembelajarannya menerapkan model pembelajaran konvesional yaitu 10,15 dan 9,03.

Dari hasil perhitungan diperoleh a sebesar 74,857 dan b sebesar 8,857 sehingga diperoleh persamaan regresi:

Cartesius: Jurnal Pendidikan Matematika Vol. 2, No. 1

CProdi Pendidikan Matematika Universitas Katolik Santo Thomas 


$$
\hat{Y}=74,857+8,857 \mathrm{X}
$$

Dari persamaan regresi tersebut dapat disimpulkan bahwa terdapat pengaruh positif antara model pembelajaran koperatif tipe STAD terhadap kemampuan pemahaman konsep matematis siswa.

Selanjutnya untuk menguji kelinearan dan keberartian (signifikansi) regresi, dapat dilihat pada tabel ANAVA berikut ini:

Tabel 5. Analisis Varians untuk Uji Kelinearan dan Keberartian Regresi

\begin{tabular}{cccccc}
\hline Sumber Varians & DK & JK & RJK & F $_{\text {hitung }}$ & F tabel \\
\hline Total & 56 & 357120 & - & - & \\
Regresi ( a ) & 1 & 352028,6 & 352028,6 & & \\
Regresi (b/a) & 1 & 1098,286 & 1098,286 & 14,852 & 4,02 \\
Sisa ( S ) & 54 & 3993,114 & 73,947 & & \\
Tuna Cocok & 9 & 0,029 & 0,003 & & \\
(TC) & & & & 3,38 & 2,10 \\
Galat ( G ) & 45 & 3993,143 & 88,736 & & \\
\hline
\end{tabular}

Berdasarkan tabel 5 untuk menguji (i) kelinearan regresi diperoleh nilai $F_{\text {tabel }}$ $=2,10$ dengan dk pembilang $(k-2)=9$ dan dk penyebut $(n-k)=45$ karena Fhitung $>\mathrm{F}_{\text {tabel }}(3,38>2,10)$ maka $\mathrm{H}_{\mathrm{o}}$ diterima dan Ha ditolak yang berarti bahwa bentuk regresi linear.

Untuk menguji hipotesis (ii) signifikansi regresi diperoleh nilai $\mathrm{F}_{\text {tabel }}=4,02$ dengan $\mathrm{dk}$ pembilang $=1 \mathrm{dan} \mathrm{dk}$ penyebut $(\mathrm{n}-2)=54$. Karena F hitung $>\mathrm{F}_{\text {tabel }}$ $(14,852>4,02)$ maka Ho ditolak dan Ha diterima yang berarti koefisien arah regresi nyata sifatnya sehingga regresi yang diperoleh berarti (signifikan).

Hasil perhitungan koefisien korelasi dengan menggunakan SPSS 22 disajikan pada tabel berikut:

Tabel 6. Hasil Analisis Korelasi pada Kelas Eksperimen

\begin{tabular}{lrrrr}
\hline Model & $\mathbf{R}$ & $\mathbf{R}$ Square & $\begin{array}{c}\text { Adjusted } \mathbf{R} \\
\text { Square }\end{array}$ & $\begin{array}{l}\text { Std. Error of } \\
\text { the Estimate }\end{array}$ \\
\hline 1 & $.464^{\mathrm{a}}$ & .216 & .201 & 8.599 \\
\hline a. Predictors: (Constant), penerapan_model &
\end{tabular}

Cartesius: Jurnal Pendidikan Matematika Vol. 2, No. 1

CProdi Pendidikan Matematika Universitas Katolik Santo Thomas 
Berdasarkan tabel 6 hasil analisis korelasi diperoleh korelasi antara model pembelajaran koperatif tipe STAD terhadap kemampuan pemahaman konsep matematis siswa dengan koefisien korelasi sebesar 0,464. Diperoleh koefisien korelasi determinasi sebesar 0,216. Dengan demikian dapat dinyatakan bahwa model pembelajaran tipe STAD mempengaruhi kemampuan pemahaman konsep matematis siswa sebesar 21,6\%, sedangkan sisanya $78,4 \%$ dipengaruhi faktor lain.

Setelah koefisien korelasi dan koefisien determinasi diperoleh, maka selanjutnya dilakukan pengujian koefisien korelasi untuk mengetahui apakah korelasi yang telah diperoleh ada artinya atau tidak. Berdasarkan perhitungan uji keberartian korelasi, diperoleh $\mathrm{t}_{\text {tabel }}=$ dengan $\mathrm{dk}=\mathrm{n}-2=54$. Dengan demikian thitung $>t_{\text {tabel }}(4,65>2,00)$ maka Ho ditolak dan Ha diterima yang artinya terdapat hubungan yang berarti antara model pembelajaran koperatif tipe STAD terhadap kemampuan pemahaman konsep matematis siswa.

Peneliti memberikan angket respon siswa dipertemuan terakhir dalam penelitian. Hasil angket respon siswa dapat dilihat pada tabel 7 berikut ini:

Tabel 7. Hasil Persentase Respon Siswa Terhadap Model Pembelajaran Koperatif Tipe STAD

\begin{tabular}{|c|c|c|c|c|c|}
\hline \multirow{2}{*}{ No. } & \multirow{2}{*}{ Indikator } & \multirow{2}{*}{$\begin{array}{l}\text { Nomor } \\
\text { Butir } \\
\text { Soal }\end{array}$} & \multirow{2}{*}{ Jumlah } & \multicolumn{2}{|c|}{$\begin{array}{c}\text { Persentase } \\
\text { respon }\end{array}$} \\
\hline & & & & $\begin{array}{l}\text { Positif } \\
\text { (S) }\end{array}$ & $\begin{array}{l}\text { Negatif } \\
\text { (TS) }\end{array}$ \\
\hline 1 & $\begin{array}{l}\text { Ketertarikan siswa terhadap } \\
\text { model pembelajaran }\end{array}$ & 1,20 & 2 & $98,2 \%$ & $1,8 \%$ \\
\hline 2 & $\begin{array}{l}\text { Manfaat yang didapat siswa } \\
\text { dengan menggunakan } \\
\text { model pembelajaran }\end{array}$ & $\begin{array}{c}2,3,5,6,1 \\
2\end{array}$ & 5 & $95,05 \%$ & $4,95 \%$ \\
\hline 3 & $\begin{array}{l}\text { Kendala yang dialami siswa } \\
\text { selama proses pembelajaran } \\
\text { menggunakan model } \\
\text { tersebut }\end{array}$ & $\begin{array}{l}4,8,9,10 \\
13,14,15 \\
17,18,19\end{array}$ & 10 & $86,78 \%$ & $13,22 \%$ \\
\hline 4 & $\begin{array}{l}\text { Harapan dan saran siswa } \\
\text { terhadap model }\end{array}$ & $7,11,16$ & 3 & $94,04 \%$ & $5,96 \%$ \\
\hline
\end{tabular}

Cartesius: Jurnal Pendidikan Matematika Vol. 2, No. 1

CProdi Pendidikan Matematika Universitas Katolik Santo Thomas 


\section{pembelajaran}

$\begin{array}{lll}\text { Rata-rata } & 93,52 \% & 6,48 \%\end{array}$

Berdasarkan hasil analisis respon siswa terhadap model pembelajaran koperatif tipe STAD, dapat disimpulkan bahwa respon siswa sangat positif terhadap model pembelajaran koperatif tipe STAD karena persentase respon siswa yang menyatakan persetujuan lebih besar dari pada persentase respon yang menyatakan ketidaksetujuan, dimana rata-rata persentase respon persetujuan siswa terhadap model pembelajaran koperatif tipe STAD $\geq 85 \%$ dalam kategori respon siswa sangat baik.

\section{PEMBAHASAN}

Berdasarkan hasil penelitian maka diperoleh temuan penelitian sebagai berikut:

1. Hasil uji hipotesis yang menggunakan uji regresi linear sederhana dan korelasi diperoleh koefisien korelasi (r) $=0,464$ artinya model pembelajaran koperatif tipe STAD mempunyai hubungan yang cukup kuat terhadap kemampuan pemahaman konsep matematis siswa, dan terdapat pengaruh model pembelajaran koperatif tipe STAD terhadap kemampuan pemahaman konsep matematis siswa pada materi SPLDV sebesar $21,6 \%$ sisanya $78.4 \%$ dipengaruhi oleh faktor lain yang tidak dianalisis dalam penelitian.

2. Untuk memperkuat hasil hipotesis dalam penelitian ini maka dilakukan analisis respon siswa terhadap model pembelajaran koperatif tipe STAD dengan menggunakan angket. Berdasarkan hasil analisis respon siswa terhadap model pembelajaran koperatif tipe STAD, dapat disimpulkan bahwa respon siswa sangat positif terhadap model pembelajaran koperatif tipe STAD karena persentase respon siswa yang menyatakan persetujuan lebih besar daripada persentase respon siswa yang menyatakan ketidaksetujuan, dimana rata-rata persentase respon persetujuan siswa terhadap model pembelajaran koperatif tipe STAD $\geq$ 85\% dalam kategori respon siswa sangat baik.

Cartesius: Jurnal Pendidikan Matematika Vol. 2, No. 1

CProdi Pendidikan Matematika Universitas Katolik Santo Thomas 
Hasil yang diperoleh dalam penelitian ini menunjukkan bahwa terdapat pengaruh model pembelajaran koperatif tipe STAD terhadap kemampuan pemahaman konsep matematis siswa dan respon siswa sangat positif terhadap model pembelajaran koperatif tipe STAD.

\section{KESIMPULAN}

Berdasarkan uraian yang telah dikemukakan pada bab sebelumnya, maka dapat dikemukakan beberapa simpulan dari penelitian ini, yaitu:

1. Berdasarkan perhitungan koefisien korelasi dengan menggunakan rumus product moment diperoleh koefisien korelasi $(\mathrm{r})=0,464$ artinya model pembelajaran koperatif tipe STAD mempunyai hubungan yang cukup kuat terhadap kemampuan pemahaman konsep matematis siswa, dan terdapat pengaruh model pembelajaran koperatif tipe STAD terhadap kemampuan pemahaman konsep matematis siswa pada materi SPLDV sebesar $21,6 \%$ selebihnya dipengaruhi oleh faktor lain yang tidak dianalisis dalam penelitian.

2. Berdasarkan hasil analisis respon terhadap model pembelajaran koperatif tipe STAD, respon siswa sangat positif terhadap model pembelajaran koperatif tipe STAD karena persentase respon siswa yang menyatakan persetujuan lebih besar daripada persentase respon siswa yang menyatakan ketidaksetujuan, dimana rata-rata persentase respon persetujuan siswa terhadap model pembelajaran koperatif tipe STAD $\geq$ 85\% dalam kategori respon siswa sangat baik.

\section{UCAPAN TERIMAKASIH}

Penulis menyampaikan terimakasih kepada Bapak Arisan Candra Nainggolan, S.Pd., M.Pd. sebagai dosen pembimbing 1 dan Ibu Imelda, S.Pd., M.Pd. sebagai dosen pembimbing 2 yang telah mengarahkan dan membimbing penulis mulai dari awal penelitian hingga berakhirnya penelitian sehingga penulis dapat menuliskan artikel ini yang merupakan bagian dari hasil penelitian penulis. Penulis juga menyampaikan terimakasih kepada kepala program studi Pendidikan Matematika, dekan, dan rektor Universitas Katolik Santo Thomas atas dukungan yang diberikan kepada penulis.

Cartesius: Jurnal Pendidikan Matematika Vol. 2, No. 1

CProdi Pendidikan Matematika Universitas Katolik Santo Thomas 


\section{DAFTAR PUSTAKA}

[1] S. Saat, "Faktor-Faktor Determinan dalam Pendidikan (Studi Tentang Makna dan Kedudukannya dalam Pendidikan)," J. Ta'dib, Vol. 8, No. 2, pp. 1-17, 2015.

[2] Nurkholis, "Pendidikan Dalam Upaya Memajukan Teknologi," J. Kependidikan, Vol. 1, No. 1, pp. 24-44, 2013.

[3] E. M. Yeni, "Kesulitan Belajar Matematika di Sekolah Dasar," Jupendas, Vol. 2, No. 2, pp. 1-10, 2015.

[4] D. Novitasari, "Pengaruh Penggunaan Multimedia Interaktif Terhadap Kemampuan Pemahaman Konsep Matematis Siswa," FIBONACCI J. Pendidik. Mat. dan Mat., Vol. 2, No. 2, pp. 8-18, 2016.

[5] F. Soewarno, Hasmiana, "Prodi Pendidikan Guru Sekolah Dasar Fakultas Ilmu Pendidikan Unsyiah Banda Aceh," J. Ilm. Mhs. Prodi PGSD FKIP Unsyiah, Vol. 1, No. 1, pp. 21-30, 2016.

[6] Malikah, "Upaya Guru Dalam Mengatasi Kesulitan Belajar Matematika Siswa Dengan Pendekatan Saintifik (Scientific Approach)," J. Sangkareang Mataram, Vol. 3, No. 2, pp. 44-48, 2017. 